Saudi Journal of Humanities and Social Sciences

Abbreviated Key Title: Saudi J Humanities Soc Sci

ISSN 2415-6256 (Print) | ISSN 2415-6248 (Online)

Scholars Middle East Publishers, Dubai, United Arab Emirate

Journal homepage: https://saudijournals.com/sjhss

Original Research Article

\title{
Reconstruction of Land Regulation of Yogyakarta's Sultanate Land Based on Justice Value
}

\author{
Sukarno $^{1 *}$, Gunarto ${ }^{2}$, Agus Pandoman ${ }^{3}$, Ratih Mega Puspa Sari ${ }^{4}$ \\ ${ }^{1}$ Doctorate Student of Faculty of Law Sultan Agung Islamic University Semarang, Indonesia \\ ${ }^{2}$ Faculty of Law Sultan Agung Islamic University Semarang, Indonesia \\ ${ }^{3}$ Faculty of Law Cokroaminoto University Yogyakarta, Indonesia \\ ${ }^{4}$ Faculty of Law Sultan Agung Islamic University Semarang, Indonesia
}

DOI: $10.36348 /$ sjhss.2020.v05i10.011 $\quad$ | Received: 07.10.2020 | Accepted: 19.10 .2020 | Published: 21.10 .2020

*Corresponding author: Sukarno

\section{Abstract}

The concept of land tenure in Indonesia is basically controlled by the state and then granted to its citizens as stipulated in the Main Agrarian Law (UUPA), but in Yogyakarta, there is a land which is specifically controlled by the sultan, thus there are two different concepts that conflict with one another which often creates legal problems related to the status of the land, these problems are then studied further by the author into research with the following problems and that is what are the weaknesses of the implementation of the current Sultanate land rights registration regulations in Yogyakarta and how is the reconstruction of the Sultanate land registration regulations based on justice values. This study uses a sociolegal research approach with data sources, namely primary data obtained in the field and relevant literature as secondary data. The data analysis used was a descriptive-analytical method. The result of the author's research shows that the weakness of land registration of the Sultanate Land in Yogyakarta is that its regulation has collided with several other regulations issued both at the central and regional levels. To overcome this, it is necessary to Reconstruct the land registration of the Sultanate for legal protection based on the value of justice is to strengthen the position of the Sultanate which is royal in nature with the government to protect the rights of local communities who control and occupy the land and buildings of the Sultanate in the Yogyakarta Special Region to increase economic growth and the welfare of the local community based on human values and justice, and legal reconstruction of Article 1 paragraph (4) of Law no. 13 of 2012 concerning the Privileges of Yogyakarta which in its implementation still respects and strengthens property rights owned by the Sultanate of the Special Region of Yogyakarta.

Keywords: Reconstruction, Juvenile, Criminal Justice, Justice Value.

Copyright (C) 2020 The Author(s): This is an open-access article distributed under the terms of the Creative Commons Attribution 4.0 International License (CC BY-NC 4.0) which permits unrestricted use, distribution, and reproduction in any medium for non-commercial use provided the original author and source are credited.

\section{INTRODUCTION}

Land Property rights, according to Indonesia's Main Agrarian Act (UUPA) are hereditary, strongest, and rightfully owned. With a hereditary character, it is the strongest and the most fulfilled place property rights as the highest level of rights in Indonesia. Property rights are rights to land that are not limited in time. Above ownership rights can be encumbered with other land rights such as building use rights and usage rights. The Indonesian land ownership, however still has many limitations as like in Yogyakarta for example.

In Yogyakarta, the government Administration is quite special as the city has been given the title of "Daerah Keistimewaan" or special region [1] by the main government since the founding of the country itself. This raises several problems as this title makes the city able to demand several special treatments unlike other cities as it is the requirement the Sultanate asks when they are invited to join Indonesia in 1945 and among this special treatment, are the treatment of of the Sultanate to have its own private land separate from the main Government's rule.

This "Special Treatment", according to the author is problematic as it violates Article 33 of Indonesian Constitutional Law which reads:

"Earth, water and natural resources contained therein shall be controlled by the State and used for the greatest prosperity of the people".

This condition where two law exists at the same place the position of the Keraton in the higher 
ground, which means that the lands will be fully owned by the Keraton. This can confirm that the land is not State land. There are consequences that arise if the status of the Palace as a legal entity that can hold property rights, namely carrying out the provisions of the Fourth Dictum clause (a) of UUPA which states that "the rights and authorities over land, water, from selfgovernment and former self-governing bodies that still exist at the time of their validity. This Law is abolished and transferred to the State" becomes invalid.

Several policies have been carried out by the Yogyakarta's Government on behalf of the implementation of this law or the existence of land owned by the Sultanate and land owned by Pakualaman (Sultanate's Royalties), which includes creating a Land Certification belonging to the Legal Entity of the Sultanate/Pakualaman /Kadipaten. Currently, data collection and registration of state lands (land that is not certified) throughout DIY to become the property of the Sultanate / Pakualaman as a private legal entity using the main government's budget (APBN), covering forests; beach; Wedi Kengser (Sultanate's Owned Land); and village land. In fact, the Head of the DIY BPN Regional Office is ready to re-examine the origins of land which has become the community's own right according to Rijksblad No. 16 and No. 18 of 1918, if it is proven that in 1918 a piece of land is not certified as ownership then the land will forcibly transfer its ownership; from community ownership rights to property rights of the Sultanate /Pakualaman, The Special Region of Yogyakarta.

Yogyakarta is a special area in Indonesia because the Sultan is the owner of the land which is the land of the Keraton. The people only have the right to lease or use rights and are usually called "Magersari". If the Sultan wants, at any time he can revoke it. Historically, land law was regulated jointly, both with village treasury lands, people's lands, and the Keraton land itself. On the other hand, the concept of land ownership according to the UUPA was land controlled by the state, thus the concepts of land ownership between the Sultanate of Yogyakarta with the concept of land ownership as regulated in the UUPA can be said as differs greatly [2].

Although from its historical context, DIY uses the old concept, namely the kingdom is the owner of the land and all existing agrarian sources. On the other hand, the UUPA was only fully effective in 1984 with the issuance of Presidential Decree No. 33 of 1984. However, DIY still has a special feature of enforcing legal relations and legal actions between the general public and state land which still uses the status of the Sultanate' Land. Sultan Ground itself is a land that is owned by the Sultanate either institutionally or individually and its use must be registered first to obtain the Kemancingan Dalem (permit to use land that belongs to the Sultanate) [3].
Seeing the various phenomena that arise in public and state life regarding Sultan Ground Land with the concept of land controlled and owned by the Sultan while on the other hand, the concept of land ownership according to the UUPA states that land is controlled by the state, thus there are two different concepts between the Yogyakarta Sultanate and the concept of ownership. Land regulated in the UUPA, these problems are then studied further by the author in to a research with the following problems:

1. What Are The Weaknesses Of The Implementation Of The Land Regulation Of Sultanate Land Rights In Yogyakarta Currently?

2. How Is The Reconstruction Of The Land Regulation Of Sultanate Land Rights In Yogyakarta Based On Justice Values?

\section{METHOD OF RESEARCH}

This study is a constructivist paradigm research that uses descriptive-analytical research. The method of approach used in research is socio-legal approach that is intended to study and examine the reciprocal relationship that is associated in real terms with other social variables [4].

Sources of data used include primary data obtained in the field and secondary data obtained from relevant literature among other things, in the form of: Legislation related to the problem discussed.

Research related to the socio-legal approach [5], namely research that analyzes problems is carried out by combining legal materials (which are secondary data) with primary data obtained in the field. Supported by first the secondary legal materials, in the form of writings from experts and agrarian law policies.

RESEARCH RESULT AND DISCUSSION
Weaknesses of the Implementation of the Land
Regulation of Sultanate Land Rights in Yogyakarta
Currently
The establishment of the city of Yogyakarta began with the Giyanti Agreement on February 13 year 1755, which was signed by the Dutch Company under the signature of Governor Nicholas Hartingh on behalf of Governor-General Jacob Mossel. The contents of the Gianti Agreement states that: The State of Mataram is divided into two, namely: Half will belong to the Kingdom of Surakarta, the other half is the right of Prince Mangkubumi. In the agreement, the role of Mangkubumi was also recognized as the King of half of the Java island and got crowned as Sultan Hamengku Buwono Senopati Ingaloga Abdul Rachman Sayidin Panatagama Khalifatullah.[6]

The areas under his control are Mataram (Yogyakarta), Pojong, Sukowati, Bagelen, Kedu, Bumigede and added with foreign regions, namely; Madiun, Magetan, Cirebon, Half Pacitan, Kartosuro, 
Kalangbret, Tulungagung, Mojokerto, Bojonegoro, Ngawen, Sela, Kuwu, Wonosari, and Grobogan.

After the completion of the Regional Division of the Agreement, the Mangkubumi Prince, who had the title Sultan Hamengku Buwono I, he immediately determined that the Mataram area under his control was named NgaYogyakarta Hadiningrat and had its capital in NgaYogyakarta (Yogyakarta). This decree was announced on March 13, 1755.

In the case of oversight of the vast land of the Sultanate, the sultan surrenders it to the relatives of the sultan (Sentana Dalem) and the employees (Priyayi) appointed by the sultan who are called "Patuh", while the land that is held to them is called "land of Patuh" or "land of lungguh (apanage)."

On this land, the Patuh can collect taxes as their income. In exercising control over the lands of the Sultanate, Patuh hand over their rights to power to their urban servants, namely the government apparatus (lurah), who have a social position below Patuh.

In the Special Region of Yogyakarta, the land given by the Sultanate to Patuh is also known as Pakualaman Land as Swapraja Land, whose existence is still recognized today. In the Law of the Republic of Indonesia Number 13 of 2012 concerning the Privileges of the Special Region of Yogyakarta, the land of the Sultanate is defined as land belonging to the Sultanate which is commonly called the Sultan Ground (SG) while the Kadipaten land is a land owned by the Puro Paku Alaman Kadipaten which is commonly called the Paku Alaman Ground. Kasultanan lands and Kadipaten lands include Keprabon lands and non-Keprabon lands [7].

In the article explanation of the Law of the Republic of Indonesia Number 13 of 2012, what is meant by Keprabon land is land used for palace buildings and their accessories, such as Pagelaran, Kraton, Sripanganti, land for the graves of kings and their relatives (in Kotagede, Imogiri, and Giri. lackluster), Alun-Alun (City Square), mosque, and Tamansari (Park), Pesanggrahan (Guest House) and petilasan (Meditation Area). Whereas non-prabon land consists of two types of land, namely land used by residents/institutions with rights (Magersari, Ngindung, Land-use rights, forests, campuses, hospitals, etc.) and land used by residents without a base. All the Keparabon lands and non-Keprabon lands will later be registered with the land agency as Sultanate land and Kadipaten land. The land agency itself means a nonministerial government agency that deals with the land sector. The existence of self-governing lands in Yogyakarta which are still recognized as inseparable from the historical existence of land in Yogyakarta itself.
In the Special Region of Yogyakarta, initially there was never any state land on it. All state land in the Special Region of Yogyakarta is Sultanate land, which since independence was given to local governments. In addition, there is land belonging to the Yogyakarta Palace (Sultan Ground), and land belonging to Puro Paku Alam (Paku Alam Ground), some of which are currently used by the community to live or cultivate with buttons or use rights certificates from the Keraton and Puro, but not proprietary. Because of its special nature, land in the Special Region of Yogyakarta should not be sufficiently regulated by the UUPA, but must be spelled out in a Regional Regulation (Perda).

The Sultan Ground (SG) and Paku Alaman Ground (PAG) are the division of the term land in the area of the Yogyakarta Hadiningrat Palace and Kadipaten Puro Paku Alaman except for lands that have been granted ownership rights to the community. This meaning refers to the domain of law which has been the basis since 1918, which was later strengthened by the DIY Regional Regulation No.5 of 1954 until then restated on April 11, 2000 at an inventory and certification ceremony for the DIY Palace lands between the local government and related institutions.

Currently, the positions of Sultan Ground and Paku Alaman Ground are recognized by both the public and the government. It is proven that if the local government wants to use land in the Yogyakarta area, they must first ask permission from the Yogyakarta Palace or Puro Paku Alaman. This means that there is no exception even to entrepreneurs who want to invest in Yogyakarta. Meanwhile, the recognition of the land of Sultan Ground and Paku Alaman Ground to the community was marked by the acceptance of the Serat Kekancingan (Permit to use Sultanate's Land) [8] in the hands of the community, with an explanation that the status of the land occupied was Magersari land or belonging to the palace. The letter was signed by Panitikismo or the palace's land agency. Panitikismo institutions such as those in the Yogyakarta palace are not found in Puro Paku Alaman and are currently only trying to be established.

Although the UUPA has been fully implemented in DIY since 1984 and Law No.13 of 2012 concerning the Privileges of the Special Region of Yogyakarta, the dualism of the land regulation still causes problem. Until now, many people still consider land issues which are part of the autonomy of the special regions Yogyakarta. Affirmation of the status of the palace and the land under control must be within the framework of the Unitary State of the Republic of Indonesia and lead to the achievement of the people's welfare so that the interests of the people must take precedence. There are three alternative options for the legal status of the Keraton for the lands of Sultan Ground and Paku Alaman Ground which should be used as a reference before the enactment of UUK No.13 of 
2012Implementation of land registration that produces certificates as a strong proof of rights, through administrative processes and operational activities and even social interactions according to legal regulations. A legal system that regulates and gives authorities the authority to perform service tasks, as well as regulates administrative procedures and requirements covering technical and juridical aspects related to the land for which registration of rights is being applied.

To what extent the effectiveness of registering property rights in legal realities and social realities is a question where analysis is needed to be carried out using sociological norms of several basic provisions regarding land registration that have potential weaknesses in implementation, whereas, with a sociological approach, it will be analyzed to what extent certificates as land registration products can provide a guarantee of legal certainty over land rights normatively and sociologically.

In the national land law system, UUPA as basic regulations is implemented by implementing regulations, including land registration regulations itself.

In order to realize legal certainty over land ownership rights, apart from being dependent on legal norms, it is also determined by law enforcement itself. It must be realized that those who apply the legal rule are humans who in applying the legal rules apart from being affected by their human aspects, are also inseparable from their influence. various situations faced including the influence of the strategic environment, such as land ownership system and community legal culture.

In connection with the objective of land registration, which guarantees certainty and protection, this condition can be pursued through orderly administration of land ownership and organized community involvement since pre-registration of land such as the Pokmasdartibnah system. This group is jointly installing land ownership boundary markers which will facilitate the creation of a basic map of registration, the process of registering land rights, and post-registration sociological protection as is done in Klaten Regency.

To realize legal certainty and real legal protection for registered landowners, a title-insurance system can be applied, so that registered rights holders can be protected, while those who win the court receive compensation payments by the insurance company.

Starting from the background idea of conducting this research and based on various opinions, it can be further argued that even though the implementation of land registration is based on positive-normative law, because it adopts a negative publication system, land registration has not guaranteed legal certainty of ownership over land as is stipulated. Even though a plot of land has been registered for rights, there are always doubts and concerns for certificate holders regarding certain legal protection.

Special treatment/authority is certain additional powers that a region has in addition to the authority as defined in the law on the regional government given by the main government. The existence of this special authority is a form of asymmetric decentralization, which is the application of special powers to certain areas of a country. Asymmetric decentralization in the form of special autonomy is a manifestation of decentralization that is adapted to regional characteristics so that its application is not uniform in every region in a country. The form of asymmetric decentralization in Indonesia is implied in Article $18 \mathrm{~B}$ paragraphs (1) and (2) of the 1945 Constitution which reads:

(1) The State recognizes and respects units of regional government that are special or special in nature as regulated in the law.

(2) The State recognizes and respects customary law community units and their traditional rights as long as they are still alive and in accordance with community development and the principles of the Unitary State of the Republic of Indonesia, which are regulated in the Law.

The Special Region of Yogyakarta has the status of a special region based on Law Number 13 of 2012 concerning the Privileges of the Special Region of Yogyakarta, which states that one of the special powers of the Special Region of Yogyakarta is in the land sector. The provision of Article 32 paragraph (1) which states that the Sultanate is a legal entity, makes the Sultanate a subject of rights that has the right to own the land of the Sultanate and has the authority to manage and utilize the Sultanate's land. In implementing the Kasultanan as a legal entity there are obstacles that arise.

The first is the stipulation of the Kasultanan as a legal entity that can grant and receive land rights as stipulated in the UUPA, thus placing the Kasultanan status as a private legal entity like other legal entities. It should be noted that the Government provides funding in order to carry out the Privileges of the Special Region of Yogyakarta. In Article 42 of Law Number 13 Year 2012 concerning the Privileges of the Special Region of Yogyakarta, the law states that:

(1) The government provides funding for the implementation of the Privileged Affairs of The Special Region of Yogyakarta as referred to in Article 7 paragraph (2) in the State Revenue and Expenditure Budget according to what The Special Region of Yogyakarta needs and the state's financial capacity 
(2) Funds in the framework of implementing the Privileges of The Special Region of Yogyakarta Regional Government as referred to in paragraph (1) shall be discussed and determined by the Government based on the submission of The Special Region of Yogyakarta Regional Government.

(3) Funds as referred to in paragraph (2) shall be in the form of Privileged funds allocated to and managed by The Special Region of Yogyakarta Regional Government, the allocation and distribution of which is through the transfer mechanism to the regions.

(4) Further provisions regarding the procedures for allocating and channeling Privileged funds are regulated by a regulation of the Minister of Finance.

(5) The Governor reports the implementation of The Special Region of Yogyakarta activities to the Government through the Minister at the end of each fiscal year as it is necessary to have an auditor for the finances of the Special Region of Yogyakarta as a private legal entity.

With the formulation the Minister of Finance Regulation and the Special Regional Regulation, it is expected that this problem can be solved because the Special Funds originating from State finances will also be used in the management of land policies in the Special Region of Yogyakarta and until now the land data collection process of the Sultanate has not been completed.

In Article 43 letter (a) of Law Number 13 of 2012 concerning the Privileges of the Special Region of Yogyakarta, the Governor as Sultan Hamengku Buwono who reigns and/or the Deputy Governor as the Adipati of Paku Alam who is in charge of inventory and identification of the Sultanate land and the Kadipaten land. In the process of inventorying and identifying the sultan's land, of course, the Sultanate must cooperate with the local Land Office. According to Benny Suharsono as Head of the Administration Bureau, Regional Secretariat, Yogyakarta Special Region Government, until 15 September 2015, the data collection process for the sultan's land and the land of Pakualaman had only reached 10,523 land plot, namely the length of the measurement process due to limited measuring instruments, limited measurement power, and also because the sultan's land data in villages and sub-districts have changed a lot.

Changes in soil shape can occur due to several things, such as landslides, eroded land, and so on. And this is compounded by the delay in the formation of the Yogyakarta Special Region Regulation (Perdais) which regulates land in Yogyakarta.

Perdais is a DIY Regional Regulation established by the DIY DPRD together with the Governor to regulate the implementation of Special Authority.
Because the issuance of the Perdais on land has not been late, services to the people who wish to propose for extension of rights and renewal of land rights in the Sultanate are hampered. The Kasultanan has stopped giving serat kekancingan (Permit to use the Sultanate's land) since early 2013. The temporary suspension was carried out for the purposes of data collection and identification of the sultan's land so that as a result the land problems of the Sultanate had accumulated that with the issuance of Perdais on these problems, it is the best step to solve the land problem of the Sultan Ground. With the formation of perdais on land, it will become a legal basis for the Sultanate and the Yogyakarta Government to exercise its special authority in the land sector. In managing the sultan's land, it is hoped that the Sultanate can prioritize the interests of the community. The exercise of authority in special affairs should be based on the values of local wisdom and side with the people.

\section{Reconstruction of the Land Regulation of Sultanate Land Rights in Yogyakarta Based On Justice Values}

Historically, the specialties in the land sector owned by the Special Region of Yogyakarta gained its legitimacy with the enactment of Law Number 13 of 2012 concerning the Privileges of the Special Region of Yogyakarta. The authority to regulate the land sector specifically appears in Articles 7, 32, 33, 34, 35, 43, 46, and 47 of these provisions. Article 7 states that land is one of the authorities in matters of Privileges owned by the Special Region of Yogyakarta.

In implementing the land authority owned by the Special Region of Yogyakarta, the NgaYogyakarta Hadiningrat Sultanate is declared a legal entity based on Article 32 paragraph (1). Furthermore paragraph (2) and paragraph (3) determine that the Kasultanan and the Kadipaten as legal entities are subjects that have ownership rights over land. The land ownership in question is the land of the Sultanate / Sultan Ground (SG), which includes Keprabon land and non-keprabon land that are found throughout the DIY area.

The land management of the Sultanate was administered by Kawedanan Hageng Punokawan Wahono Sarto Kriyo and the Office of the Paniti Kismo Keraton, NgaYogyakarta. No.16 of 1918 which reads:

"Sakabehing bumi kang ora ana tandha yektine kadarben ing liyan, mawa wenang eigendom, dadi bumi kagunganne Kraton Ingsun NgaYogyakarta (All the land that does not have the true sign of contentment in others, with eigendom authority, becomes the land of the Kingdom of Yogyakarta)".

This provision stated that all land that did not have proof of ownership or was not under the authority of the colonial government's Eigendom/ property rights became land belonging to the NgaYogyakarta Palace. Technically, this stipulation claims that all land in 
Special region of Yogyakarta which is not certified as ownership is a land owned by the Sultanate. Therefore, the Kasultanan / Kraton as a legal subject that has the status of a legal entity and has ownership rights to the Sultanate Land (SG).

The consequence of granting the status of a legal entity to the Kraton makes it a legal subject to have ownership rights over land. Property rights in the UUPA are hereditary, strongest, and fullest rights. With the characteristics contained in property rights, it places them as the highest level of rights. Property rights are not limited to the period of time. Above property rights can be encumbered with other land rights, such as building use rights and usage rights. With the existence of property rights, the position of the Kraton is very strong, so that the lands will become fully owned by the Kraton. This can confirm that these lands are not stateowned land. So the consequences arise if the Kraton status as a legal entity that has property rights, namely the provisions in Dictum IVA UUPA which states that:

"Rights and authority over land, water, from self-government. and former self-governmental organizations that still exist at the time this Law comes into force are abolished and transferred to the State "becomes invalid.

The status of a legal entity for the Kasultanan is a special legal entity established under Law no. 13 of 2012. Meanwhile, according to the legal classification, legal entities are divided into public legal entities and private legal entities (civil). If it is correlated with the nature of a legal entity that has property rights, the status of a legal entity owned by the Kraton is similar to that of a private legal entity [9].

However, when viewed from the Kraton as a royal entity that has territory or territory, it is similar to a public legal entity where, as a comparison, by looking at the policies of other countries that have similarities in terms of land law in general and land registration systems in particular in Singapore and Australia, and Malaysia.

The government should pay attention to the existence of the Yogyakarta's Sultanate and the community members who live on the borderline Sultanate lands. Rivers, particularly the Government of the Special Region of Yogyakarta, to carry out legal reconstruction in an effort to provide legal certainty and protection of land tenure over the land of the Sultanate and or the Sultan Ground so as to create a more just life for the people who live on the Sultanate's land.

The purpose of Law Number 13 of 2012 concerning the Special Region of Yogyakarta is that the purpose of the formation of this Law is to:

a. Realize a democratic government;

b. Create public welfare and peace; c. Realize governance and social order that guarantees unity-in-diversity within the framework of the Unitary State of the Republic of Indonesia;

d. Create good governance, and

e. Institutionalize the roles and responsibilities of the Sultanate and the Kadipaten in maintaining and developing the Yogyakarta culture, which is the nation's cultural heritage.

Based on the description above, the reconstruction of the Sultanate's Land Regulation in the area of the special region of Yogyakarta based on the value of justice is by strengthening the existence of the Sultanate as a kingdom which is part of the territory of the Unitary State of the Republic of Indonesia, it is hoped that the Sultanate and community members will in a long time have the status of control over land rights and buildings that have been controlled can be upgraded to the status of control over land rights, land rights and buildings, control over land and building rights as guaranteed legal certainty, which can then be registered by the owner in order to obtain proof of ownership in the form of a certificate in accordance with PP. 24 of 1997 concerning Land Registration [10].

By strengthening the function of the government and the Sultanate to protect the holders of land rights in the Sultanate who have not been interrupted from generation to generation until now as owners of land and building rights in the Special Region of Yogyakarta, there is no need for permission from the Yogyakarta Sultanate to provide assurance and legal protection for the community. so as to increase the economic growth and welfare of people who own land and buildings in the Special Region of Yogyakarta and or local communities based on human values and justice and legal reconstruction of Article 1 point (4), Article 32 paragraph 5, and Article 33 paragraph 3 of Law no. 12 of 2013 concerning the Privileges of the Special Region of Yogyakarta that must be conducted while respecting the rights to land controlled and occupied by members of the local community, therefore in order to gradually increase economic growth [11], it will be registered to obtain land titles on land in the Sultanate for community members who have occupied and controlled the land in descending order. Disconnected, or based on a permit obtained based on correct procedures in accordance with the provisions of law.

With this reconstruction, it is hoped that the attitude of the community members who care and feel responsible for implementing the rule of law, so that life is more orderly, orderly, and plays an active role in maintaining the sustainability of the Sultanate's land can grow well so that it can prosper the surrounding community.

\section{CONCLUSION}

1. Weaknesses of Yogyakarta's Sultanate land regulation to control over land and building rights 
are collided by several regulations issued both at the central level which are still multi-interpretative, still limited in number and quality of human resources from government officials, still very birocratic and convoluted so that The land registration process seems expensive and takes a long time, the slow resolution of problems in the land sector in general and the Sultanate land in particular and no permission has been granted for residents of the Special Region of Yogyakarta who occupy and control the land of the Sultanate from generation to generation until now it remains with Anggaduh (Limited ownership) rights.

2. Reconstruction of land registration of the Sultanate for legal protection based on the value of justice is by strengthening the position of the Sultanate which is royal in nature with the government to protect the rights of local communities who control and occupy the land and buildings of the Sultanate in the Special Region of Yogyakarta to increase economic growth and the welfare of local communities based on human values and justice, and legal reconstruction of Article 1 paragraph (4) of Law no. 13 of 2012 concerning the Privileges of Yogyakarta, which in its implementation still respects and strengthens the property rights owned by the community, to increase economic growth and the welfare of the local community which will gradually be registered to obtain land rights certificates while still paying attention to the socio-cultural conditions of the people who have lived in decline for generations in the Yogyakarta Sultanate.

\section{REFERENCE}

1. Utomo, S. (2018). Nilai-nilai Kearifan Lokal Hukum Adat dalam Hukum Tanah Nasional. Jurnal Hukum Media Bhakti, 2(1), 1218.
2. Radjagukguk, E. (1978). Beberapa masalah dalam hukum tanah indonesia. Jurnal Hukum \& Pembangunan, 8(3), 251-259.

3. Hasim, R. A. (2016). Politik hukum pengaturan sultan ground dalam undang-undang no. 13 tahun 2013 tentang keistimewaan Yogyakarta dan hukum tanah nasional. Arena Hukum, 9(2), 207224.

4. Mukti Fajar, N. D., \& Achmad, Y. (2010). Dualisme Penelitian Hukum: Normatif \& Empiris. Pustaka Pelajar.

5. Soerjono, S. (1984). Pengantar Penelitian Hukum, Jakarta, UI Press, 52.

6. Huda, N. M. (2000). Beberapa Kendala dalam Penyelesaian Status Hukum Tanah Bekas Swapraja di Daerah Istimewa Yogyakarta. Jurnal Hukum IUS QUIA IUSTUM, 7(13), 90-106.

7. Soedarso, P. (1982). Tentang kedudukan tanah tongkonan dalam hukum tanah positif. Jurnal Hukum \& Pembangunan, 12(5), 410-415.

8. Tribun News (2017). Ini 4 Jenis Serat Kekancingan yang Harus Dikenali Penghuni Sultan Ground dan Pakualam Ground, taken from https://jogja.tribunnews.com/2017/12/14/ini-4jenis-serat-kekancingan-yang-harus-dikenalipenghuni-sultan-ground-dan-pakualam-ground on December 2019.

9. ISMAIL, I., Sufyan, T., \& Azhari, T. (2016). Rekonseptualisasi hak atas tanah dalam kerangka pembaharuan hukum tanah nasional. LITIGASI, 14(1).

10. Fauzi, F. (2020). Hak Usaha Bagi Hasil Tanah Pertanian Ditinjau dari Hukum Tanah Nasional dan Hukum Islam, 10. 53-77.

11. Widodo, W., Budoyo, S., \& Pratama, T. G. W. (2018). The role of law politics on creating good governance and clean governance for a freecorruption Indonesia in 2030. The Social Sciences, 13(8), 1307-1311. 